\title{
Effect of structural order on oxidation kinetics and oxide phase evolution of
}

\author{
Al-Zr alloys \\ Yifei Xu ${ }^{1}$, Lars P. H. Jeurgens ${ }^{2}$, Yuan Huang ${ }^{1}$, Chong $\mathrm{Li}^{1}$, Yongchang Liu ${ }^{1}$, Zumin Wang ${ }^{1, *}$

\begin{abstract}
${ }^{1}$ School of Materials Science and Engineering, Tianjin University, Tianjin 300350, China
${ }^{2}$ Swiss Federal Laboratories for Materials Science and Technology, Laboratory for Joining Technologies and Corrosion, Ueberlandstrasse 129, 8600 Duebendorf, Switzerland
\end{abstract} \\ *E-mail: z.wang@tju.edu.cn
}

\section{Highlights}

- The fundamental role of atomic structure on thermal oxidation of alloys is revealed.

- $\mathrm{Al}-\mathrm{Zr}$ was selected as the model alloy system to circumvent preferential oxidation effect.

- Structural order of parent alloys influences strikingly oxide compositions and oxidation kinetics.

- Underlying mechanisms were disclosed by ab initio calculations and molecular dynamics simulations.

- The study offers a new perspective in the field of surface engineering.

This document is the accepted manuscript version of the following article: Xu, Y., Jeurgens, L. P. H., Huang, Y., Li, C., Liu, Y., \& Wang, Z. (2019). Effect of structural order on oxidation kinetics and oxide phase evolution of A1-Zr a1loys. Corrosion Science. https://doi.org/10.1016/j.corsci.2019.108407 


\section{Abstract}

To reveal the fundamental role of structural order of the parent alloy on the oxidation mechanism, thermal oxidation of amorphous and crystalline $\mathrm{Al}-\mathrm{Zr}$ alloys with identical compositions were investigated in detail. $\mathrm{An}\left(\mathrm{Al}_{0.68} \mathrm{Zr}_{0.32}\right) \mathrm{O}_{1.66}$ amorphous oxide emerged on crystalline $\mathrm{Al}_{2} \mathrm{Zr}$, whereas an $\left(\mathrm{Al}_{0.33} \mathrm{Zr}_{0.67}\right) \mathrm{O}_{1.83}$ amorphous oxide formed on amorphous $\mathrm{Al}_{68 \text { at.\% }} \mathrm{Zr}_{32 \text { at.\% }}$ under the same conditions. Oxidation kinetics was fast and linear for crystalline $\mathrm{Al}_{2} \mathrm{Zr}$ but slow and parabolic for amorphous $\mathrm{Al}_{68 \mathrm{at} . \%} \mathrm{Zr}_{32 \mathrm{at} . \%}$. The underlying mechanisms of such striking differences were disclosed by molecular dynamics simulations. The findings thus offer new prospects in the field of surface engineering.

Keywords: oxidation; oxidation kinetics; structural disordering; amorphous alloy; Al-Zr alloy 


\section{Introduction}

The oxide layer developing on an alloy surface during thermal oxidation influences many important material properties, such as corrosion resistance, catalytic activity, adhesion, friction, wear and long-term reliability, biocompatibility, conductivity, and optical properties [1-8]. The oxide layer produced on the alloy can be amorphous or crystalline, depending on numerous factors, such as the difference between the bulk Gibbs energies of the amorphous and crystalline states of the competing oxide phases, the participating surface and interface energies, the initial lattice mismatch with the parent substrate, the oxide layer thickness, the alloy composition, and the oxidation temperature [9-16]. Because of the relatively large free volume and bond flexibility of amorphous oxides, growth stresses and thermally induced stresses may be partly accommodated by viscous flow, thereby promoting adhesion across the substrate-film interface [9, 17-20]. Moreover, the absence of grain boundaries and other lattice defects in amorphous oxides decreased the number of fast short-circuit diffusion paths, thereby promoting the formation of chemically and structurally homogeneous oxide layers of highly uniform thicknesses. Consequently, amorphous oxide layers often exhibit favourable properties unlike their crystalline counterparts, such as improved corrosion resistance [21] and high optical transparency [22]. For instance, oxidation-resistant amorphous coatings have been used to protect the metallic alloys in various corrosive environments [4, 21]; amorphous oxides such as $\mathrm{SiO}_{2}$ and $\mathrm{Al}_{2} \mathrm{O}_{3}$ are widely used as tunnelling barriers in microelectronics [23] and amorphous oxide semiconductors (e.g. In-Ga-Zn-O) are used in modern thin-film transistors [5].

Admittedly, one important downside of functional amorphous oxide layers is their 
limited thermodynamic stability at elevated temperatures, which is typically governed by the kinetic barrier for heterogeneous nucleation of the competing crystalline oxide phase(s) at the substrate-oxide interface [24]. In this regard, it is necessary to clarify how the crystallinity of the parent alloy substrate actually influences the formation and thermal stability of amorphous oxide layers on the parent alloy substrate by thermal oxidation. In other words, the thermal oxidation of an amorphous alloy of a given homogenous composition likely differs from its crystalline counterpart due to the disordered atomic arrangement and the lack of grain boundaries (GBs) and other lattice defects in the former. The role of GBs in the parent alloy in determining oxygen diffusion has been reported previously $[25,26]$ : GBs provide short-circuit paths for enhanced outward diffusion of alloy constituents as well as fast inward diffusion of oxygen. Previous studies on the thermal oxidation of (hydrogenated) amorphous and (poly-) crystalline silicon indicate a significant effect of the crystallinity of the parent substrate on the growth kinetics and stress state of the developing amorphous $\mathrm{SiO}_{2}$ film [27, 28]. A systematic, comparative study on the thermal oxidation of an alloy of identical composition in its amorphous and crystalline state is needed to illustrate the fundamental role of atomic structure of the parent alloy on its oxidation behaviour. For such a comparative oxidation study, the alloy constituents should ideally exhibit a similar affinity for oxygen as well as comparable Gibbs energies of formation, $\Delta_{\mathrm{f}} G^{0}$ (in kJ per mole oxygen), for the competing amorphous and crystalline oxide phase formation. As such, selective oxidation issues can be largely neglected. In this respect, the Al-Zr binary system is a highly suitable candidate because the alloy constituents (i.e. Al and $\mathrm{Zr}$ ) have similar affinities towards oxygen and the Gibbs energies of formation (per mole of oxygen) for all competing 
amorphous and crystalline $\mathrm{ZrO}_{2}$ and $\mathrm{Al}_{2} \mathrm{O}_{3}$ single-oxide phases are also comparable [24].

Weller et al. [14, 29] systematically investigated the thermal oxidation of amorphous $\mathrm{Al}-\mathrm{Zr}$ alloys in the temperature range of $350-400{ }^{\circ} \mathrm{C}$ (under atmospheric pressure), revealing the thermodynamically preferred formation of a stoichiometric amorphous $\left(\mathrm{Al}_{0.33} \mathrm{Zr}_{0.67}\right) \mathrm{O}_{1.83}$ phase over a large compositional range of the parent alloy. In this work, thermal oxidation of the am-Al ${ }_{68 a t . \%} \mathrm{Zr}_{32}$ at.\% solid solution was compared to that of the $\mathrm{c}-\mathrm{Al}_{2} \mathrm{Zr}$ intermetallic alloy with an identical composition, and the role of lattice disorder in the parent alloy in determining the evolution of the oxide phase during thermal oxidation was revealed.

\section{Experimental and computational methods}

\subsection{Materials}

The $\mathrm{c}-\mathrm{Al}_{2} \mathrm{Zr}$ ingots were prepared in a magnetic levitation melting furnace by melting pure $\mathrm{Al}$ (purity 99.999 wt.\%) and pure $\mathrm{Zr}$ (purity 99.99 wt.\%) under the protection of pure Ar gas (purity 99.995 vol.\%, 0.4 bar). The raw mixture of (well-weighted) $\mathrm{Al}$ and $\mathrm{Zr}$ was melted at $1750{ }^{\circ} \mathrm{C}$ and solidified in the furnace repeatedly for 4 cycles to improve the purity and homogeneity of the alloy, and finally cast to form the c- $\mathrm{Al}_{2} \mathrm{Zr}$ ingots. The thus-prepared c- $\mathrm{Al}_{2} \mathrm{Zr}$ ingots were cut into pieces with dimensions of $5 \times 10 \times 2 \mathrm{~mm}^{3}$, followed by polishing using a series of $\mathrm{SiC}(\# 600-\# 7000)$ and diamond $(0.5-0.1 \mu \mathrm{m})$ abrasive papers until a mirror-like surface was obtained. After polishing, the specimens were ultrasonically cleaned sequentially in acetone and ethanol and finally dried by blowing with compressed $\mathrm{N}_{2}$ gas.

The am- $\mathrm{Al}_{68 \text { at.\% }} \mathrm{Zr}_{32 \text { at.\% }}$ alloys were deposited on $50-\mathrm{nm} \quad \mathrm{Si}_{3} \mathrm{~N}_{4} / 50-\mathrm{nm} \quad \mathrm{SiO}_{2} / \mathrm{Si}(100)$ wafers by co-sputtering pure $\mathrm{Al}$ (purity $\geq 99.9995$ wt.\%, target power $=101 \mathrm{~W}$ ) and $\mathrm{Zr}$ (purity $\geq 98.5$ wt. $\%$, target power $=100 \mathrm{~W}$ ) targets in a high-vacuum sputter system (base 
pressure $<5 \times 10^{-8} \mathrm{mbar}$ ), with a deposition rate of $\sim 11 \mathrm{~nm} / \mathrm{min}$ [29].

\subsection{Thermal oxidation}

The $\mathrm{c}-\mathrm{Al}_{2} \mathrm{Zr}$ specimens were sealed in quartz tubes for thermal oxidation in a vacuum sealing system (MRVS-3002, Partulab Technology Co. Ltd). The tubes were first evacuated (base pressure $\sim 1 \mathrm{~Pa}$ ) and then backfilled with pure oxygen (purity 99.999 vol. \%) for three cycles. Oxygen partial pressures $\left(p_{\mathrm{O}_{2}}\right)$ at room temperature were $p_{\mathrm{O}_{2}}=0.47$ bar, $p_{\mathrm{O}_{2}}=0.45$ bar and $p_{\mathrm{O}_{2}}=0.44$ bar corresponding to $p_{\mathrm{O}_{2}}=1$ bar at 350,375 and $400{ }^{\circ} \mathrm{C}$, respectively. The sealed quartz tubes were isothermally heated at 350,375 and $400{ }^{\circ} \mathrm{C}$ for $10 \mathrm{~h}$ in a tube furnace (OTF-1200X, Hefei Kejing Materials Technology Co. Ltd.). After the thermal oxidation, the quartz tubes were taken out of the furnace and quenched immediately in water to room temperature.

An $\mathrm{Au}$ marker experiment was designed to clarify the atomic transport mechanism during the oxidation of the $\mathrm{c}-\mathrm{Al}_{2} \mathrm{Zr}$ and am- $\mathrm{Al}_{68 \mathrm{at} . \%} \mathrm{Zr}_{32 \mathrm{at} . \%}$ alloys. To this end, an ultra-thin (thickness $\sim 2 \mathrm{~nm}$ ) Au film was deposited on the c- $\mathrm{Al}_{2} \mathrm{Zr}$ and am- $\mathrm{Al}_{68 \text { at. } \%} \mathrm{Zr}_{32 \mathrm{at} . \%}$ alloys by magnetron sputtering of pure $\mathrm{Au}$ (purity 99.999 wt. \%) in a high-vacuum sputter system (employing a target power of $10 \mathrm{~W}$ for $90 \mathrm{~s}$ ). The $\mathrm{Au}$-covered c- $\mathrm{Al}_{2} \mathrm{Zr}$ and am- $\mathrm{Al}_{68 \text { at. } \%} \mathrm{Zr}_{32 \mathrm{at} . \%}$ alloys were then oxidized at $400{ }^{\circ} \mathrm{C}$ for $10 \mathrm{~h}$.

\subsection{Analysis and data evaluation}

Atomic force microscopy \& Optical microscopy (AFM \& OM): AFM operated in tapping mode with a scan frequency of $0.878 \mathrm{~Hz}$ was used to measure the surface structure and roughness of the as-polished $\mathrm{c}-\mathrm{Al}_{2} \mathrm{Zr}$ alloys. The $\mathrm{c}-\mathrm{Al}_{2} \mathrm{Zr}$ alloys were then corroded $\left(\mathrm{H}_{2} \mathrm{O}: \mathrm{HNO}_{3}: \mathrm{HF}=10: 1: 1\right.$ volume ratio) for $3 \mathrm{~s}$ and investigated on an Olympus B41M optical 
microscope.

X-ray diffraction (XRD): The as-received and oxidized $\mathrm{c}-\mathrm{Al}_{2} \mathrm{Zr}$ alloys were investigated by XRD on a Bruker D8 Advanced diffractometer equipped with a $\mathrm{Cu}$ X-ray anode $(40 \mathrm{kV} / 40 \mathrm{~mA}, \lambda=1.5418 \AA)$. The diffractometer is in a Bragg-Brentano geometry and the XRD measurements were carried out in a $\theta-2 \theta$ mode. The scanning range of the diffraction angle $2 \theta$ was $10-70^{\circ}$, with a step size of $0.02^{\circ}$ and a detecting time of $0.15 \mathrm{~s} / \mathrm{step}$.

Spectroscopic Ellipsometry (SE): SE (ME-L ellipsomerer, Wuhan Eoptics Technology Co. \& J.A. Woollam M-2000) was used to determine the thicknesses of oxide layers on the c- $\mathrm{Al}_{2} \mathrm{Zr}$ alloys oxidized at $350-400{ }^{\circ} \mathrm{C}$. The ellipsometric values $\Psi(\lambda, \varphi)$ and $\Delta(\lambda, \varphi)$ were recorded from the as-polished and the oxidized $\mathrm{c}-\mathrm{Al}_{2} \mathrm{Zr}$ alloys over the wavelength of $\lambda=380-1000 \mathrm{~nm}$ at incidence angles of $\varphi=60^{\circ}, 65^{\circ}$ and $70^{\circ}$. Thicknesses of oxide films were determined by linear-least squares (LLS) fitting of $\Psi(\lambda, \varphi)$ and $\Delta(\lambda, \varphi)$ using the WVASE software package (version 3.880). The optical model of the oxide/substrate system used for the fitting constituted three layers of uniform thicknesses, i.e. the $\mathrm{c}-\mathrm{Al}_{2} \mathrm{Zr}$ alloy substrate, the oxide overlayer (of uniform thickness: $L_{\text {ox }}$ ) and an interfacial sublayer (of uniform thickness: $L_{\text {inter }}$ ) between the substrate and the oxide overlayer [29]. The oxide layer is optically transparent over the investigated wavelength range $(k(\lambda)=0)$ and thus the optical constants of the oxide layer were fitted by a Cauchy function $n(\lambda)=\mathrm{A}+\mathrm{B} / \lambda^{2}$. The optimized Cauchy constants were $\mathrm{A}=1.824, \mathrm{~B}=0.02 \mu \mathrm{m}^{2}$ for $350{ }^{\circ} \mathrm{C}, \mathrm{A}=1.836, \mathrm{~B}=0.02 \mu \mathrm{m}^{2}$ for $375{ }^{\circ} \mathrm{C}$, and $\mathrm{A}=1.848, \mathrm{~B}=0.02 \mu \mathrm{m}^{2}$ for $400{ }^{\circ} \mathrm{C}$, respectively. This corresponds to a refractive index at $\lambda=632.8 \mathrm{~nm}$ of $n=1.874$ at $350{ }^{\circ} \mathrm{C}, n=1.886$ at $375{ }^{\circ} \mathrm{C}$ and $n=1.898$ at $400{ }^{\circ} \mathrm{C}$, considerably higher than that of $\alpha-\mathrm{Al}_{2} \mathrm{O}_{3}(n=1.765$ [30] and $n=1.772$ [31] at $\lambda=632.8$ 
$\mathrm{nm})$, but lower than that of $\mathrm{t}_{\mathrm{ZrO}}(n=2.192$ [32] and $n=1.976$ [33] at $\lambda=632.8 \mathrm{~nm}$, and also the optical data in the Ref. [34]) and the oxide film on the am- $\mathrm{Al}_{0.44} \mathrm{Zr}_{0.56}$ alloy $(2.090 \leq n \leq 2.119$ [24] at $\lambda=600 \mathrm{~nm})$. The optical properties of the interfacial sublayer were approximated from the optical properties of the substrate and the oxide overlayer using the Bruggeman effective medium approximation (while taking equal volume percentages for the substrate and the oxide, i.e. 50:50). The total thickness of oxide layer, $d_{\mathrm{ox}}$, was taken as $d_{\mathrm{ox}}=L_{\mathrm{ox}}+0.5 L_{\mathrm{inter}}$.

Auger electron spectroscopy (AES): The oxidized c- $\mathrm{Al}_{2} \mathrm{Zr}$ alloys were investigated by AES sputter-depth profiling in a PHI 700Xi scanning Auger nanoprobe system (base pressure $5 \times 10^{-7} \mathrm{~Pa}$ ), with a field-emission electron gun operated at $5 \mathrm{keV}$. Sputter-depth profiling was performed with a focused $2 \mathrm{kV} \mathrm{Ar}{ }^{+}$beam rastering the surface (sputter rate: $2 \mathrm{~nm} / \mathrm{min}$ for $\mathrm{SiO}_{2}$ ), scanning an area of $100 \times 100 \mu \mathrm{m}^{2}$. The spectra of the $\mathrm{Al} K L L, \mathrm{Zr} M N N$ and $\mathrm{O} K L L$ Auger electrons were recorded after each successive sputtering step. The concentration-depth profiles of the oxidic and metallic $\mathrm{Al}$ and $\mathrm{Zr}$ were obtained by LLS fitting of the corresponding differential AES spectra (MultiPak, v 9.5.0.8). The quantifications of $\mathrm{Al}$ and $\mathrm{Zr}$ in their metallic $\left(\mathrm{Al}^{\text {met }}\right.$ and $\left.\mathrm{Zr}^{\text {met }}\right)$ and oxidic $\left(\mathrm{Al}^{\mathrm{ox}}\right.$ and $\left.\mathrm{Zr}^{\mathrm{ox}}\right)$ states, as well as of $\mathrm{O}$, were carried out according to the procedure described in Ref. [24], while employing the following relative sensitivity factors $S$ (with respect to metallic $\mathrm{Zr}$ ): $S_{\mathrm{Zr}^{\mathrm{met}}}=1.000, S_{\mathrm{Zr}^{\mathrm{ox}}}=0.627$, $S_{\mathrm{Al}^{\mathrm{met}}}=0.178, S_{\mathrm{Al}^{\mathrm{ox}}}=0.411$ and $S_{\mathrm{O}}=1.312$.

Transmission electron microscopy (TEM): Cross-sectional TEM lamella were prepared using a so-called 'tripod-polishing method' [35]. The c- $\mathrm{Al}_{2} \mathrm{Zr}$ specimen oxidized at $400{ }^{\circ} \mathrm{C}$ for $10 \mathrm{~h}$ was investigated by TEM in a JEOL JEM-2100F microscope operated at an 
acceleration voltage of $200 \mathrm{kV}$.

\subsection{Computational methods}

The oxygen diffusivities in the c- $\mathrm{Al}_{2} \mathrm{Zr}$ and am- $\mathrm{Al}_{68 \mathrm{at} . \%} \mathrm{Zr}_{32 \mathrm{at} . \%}$ alloys were simulated using the Forcite module in the software Materials Studio (MS) using the universal force field (UFF) [36] including bond order assignment, in which parameter generation is based on physically realistic rules. The $\mathrm{c}-\mathrm{Al}_{2} \mathrm{Zr}$ alloy was modelled using a $3 \times 3 \times 3$ unit cell (lattice parameters: a $=\mathrm{b}=15.843 \AA, \mathrm{c}=26.226 \AA, \alpha=\beta=90^{\circ}$ and $\gamma=120^{\circ}$ ). To obtain the structural model of the

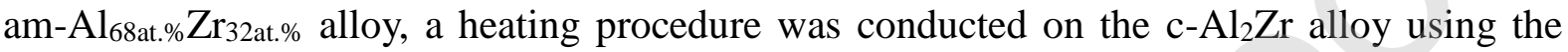
temperature cycle protocol in the Forcite module. The NVT [37] ensemble with a Nose thermostat was selected to optimize the equilibration system. The $\mathrm{c}-\mathrm{Al}_{2} \mathrm{Zr}$ was heated over its melting temperature $(4000 \mathrm{~K})$ and then quenched to room temperature at a rate of $1 \times 10^{12} \mathrm{~K} / \mathrm{s}$. A final equilibrium step was run for $5 \mathrm{~ns}$. The amorphous configuration of simulated alloy is confirmed based on the radial distribution function (RDF) of the am-Al ${ }_{68 a t . \%} \mathrm{Zr}_{32 \text { at.\% }}$ alloy [38]. To simulate the oxygen diffusion in the $\mathrm{c}-\mathrm{Al}_{2} \mathrm{Zr}$ and am- $\mathrm{Al}_{68 \text { at.\% }} \mathrm{Zr}_{32 \text { at.\% }}$ alloy system, respectively, an oxygen atom was introduced into the respective simulation cell with random initial velocities. Geometry optimization was performed for the initial cell with the conjugate gradient (CG) algorithm [39]. The convergence criterions were $1 \times 10^{-4} \mathrm{kcal} / \mathrm{mol}$ for energy, $5 \times 10^{-4} \mathrm{kcal} / \mathrm{mol} / \AA$ for force, $5 \times 10^{-4} \mathrm{GPa}$ for stress, and $5 \times 10^{-5} \AA$ for atomic displacement. After iteration for 500 times, the external pressure was adjusted to $10^{-5} \mathrm{GPa}$. During the simulation of oxygen diffusion in c- $\mathrm{Al}_{2} \mathrm{Zr}$ and am- $\mathrm{Al}_{68 \mathrm{at} .} \% \mathrm{Zr}_{32 \mathrm{at} .} \%$ at 350,375 , and $400{ }^{\circ} \mathrm{C}$, the time-step was set at $1 \mathrm{fs}$ and the total simulation time was maintained at around $10 \mathrm{~ns}$.

\section{Results}




\subsection{Oxide microstructure}

The XRD pattern of the as-received c- $\mathrm{Al}_{2} \mathrm{Zr}$ specimen confirmed that the alloy was composed of a single-phase intermetallic phase with a hexagonal close-packed (hcp) structure (Fig. 1a). The $\mathrm{c}-\mathrm{Al}_{2} \mathrm{Zr}$ alloy showed a very large average grain size (>10 $\mu \mathrm{m}$, Fig. 1b) and, consequently, the influence of alloy GBs on the oxidation behaviour of the crystalline alloy could be neglected in this case. The surface of $\mathrm{c}-\mathrm{Al}_{2} \mathrm{Zr}$ after polishing (before oxidation) was very smooth with an average RMS (root-mean-squared) roughness below $1 \mathrm{~nm}$, as determined by AFM (Fig. 1c).

After thermal oxidation of $\mathrm{c}-\mathrm{Al}_{2} \mathrm{Zr}$ at 350 and $400{ }^{\circ} \mathrm{C}$ for $10 \mathrm{~h}$, no additional diffraction peaks could be detected for the alloy and/or oxide by XRD (Fig. 1a). This suggests that the oxide layers formed on the c- $\mathrm{Al}_{2} \mathrm{Zr}$ alloys were fully amorphous. The $\mathrm{c}-\mathrm{Al}_{2} \mathrm{Zr}$ oxidized at $400{ }^{\circ} \mathrm{C}$ for $10 \mathrm{~h}$ was also investigated by cross-sectional TEM (Fig. 2a; a selected-area diffraction (SAD) pattern taken for the $\mathrm{c}-\mathrm{Al}_{2} \mathrm{Zr}$ alloy substrate is shown in the inset). TEM analysis confirmed the formation of a homogenous oxide layer of uniform thickness (36 nm) on the surface of $\mathrm{c}-\mathrm{Al}_{2} \mathrm{Zr}$. A high-resolution TEM (HRTEM) image of the oxide/c- $\mathrm{Al}_{2} \mathrm{Zr}$ interfacial region, marked by the rectangle in Fig. 2a, is shown in Fig. 2b. According to the fast Fourier transform (FFT) of the image in Fig. 2b (inset of Fig. 2b), the oxide layer was also fully amorphous.

The interface between the $\mathrm{c}-\mathrm{Al}_{2} \mathrm{Zr}$ alloy and the oxide layer was relatively well defined (i.e. not diffuse). Possible enrichment (segregation) of $\mathrm{Al}$ or $\mathrm{Zr}$ at the alloy/oxide interface could not be detected by analytical TEM (Fig. 3). Corresponding energy-dispersive X-ray spectroscopy (EDX) element mapping of the $\mathrm{c}-\mathrm{Al}_{2} \mathrm{Zr}$ alloy oxidized at $400{ }^{\circ} \mathrm{C}$ for $10 \mathrm{~h}$ 
indicated homogenous distribution of $\mathrm{O}, \mathrm{Zr}$ and $\mathrm{Al}$ in the amorphous oxide layer (Fig. 3). Quantitative EDX analysis of acquired $\mathrm{Al} K, \mathrm{Zr} K$, and $\mathrm{O} K$ lines suggested a nominal composition of 41 at.\% $\mathrm{Al}, 23 \mathrm{at} . \% \mathrm{Zr}$, and 36 at.\% $\mathrm{O}$ for the amorphous oxide layer. The corresponding $\mathrm{Al}^{3+} / \mathrm{Zr}^{4+}$ atomic ratio in the oxide layer of about 2 agreed well with the respective $\mathrm{Al} / \mathrm{Zr}$ atomic ratio of 2 for the underlying $\mathrm{c}-\mathrm{Al}_{2} \mathrm{Zr}$ alloy.

It was concluded that prolonged thermal oxidation of the c- $\mathrm{Al}_{2} \mathrm{Zr}$ alloy at 350 and $400{ }^{\circ} \mathrm{C}$ resulted in the formation of a chemically homogenous, amorphous $\mathrm{Al}-\mathrm{Zr}-\mathrm{O}$ overlayer of uniform thickness.

\subsection{Oxide composition}

As evidenced by the obtained AES depth profiles, the amorphous oxide overlayers grown on the c- $\mathrm{Al}_{2} \mathrm{Zr}$ alloy (oxidized at 350,375 , and $400{ }^{\circ} \mathrm{C}$ for $10 \mathrm{~h}$ ) had a fixed stoichiometric bulk composition (i.e. in the interior part) of $\left(\mathrm{Al}_{0.68} \mathrm{Zr}_{0.32}\right) \mathrm{O}_{1.66}$, which was in agreement with the EDX results (Fig. $4 \mathrm{a}-\mathrm{c}$ ). Hence, the average atomic ratio of $\mathrm{Al} / \mathrm{Zr}\left(=2^{ \pm 0.1}\right)$ of the oxide overlayer fairly matched that of the $\mathrm{c}-\mathrm{Al}_{2} \mathrm{Zr}$ substrate. Surprisingly, the oxide overlayers

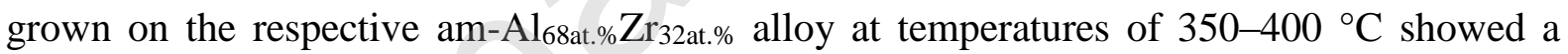
very different composition of $\left(\mathrm{Al}_{0.33} \mathrm{Zr}_{0.67}\right) \mathrm{O}_{1.83}$ (Fig. 4d-f) [14]. This implies that the oxide layers on the am- $\mathrm{Al}_{68 \mathrm{at} . \%} \mathrm{Zr}_{32 \text { at.\% }}$ alloy were much more enriched with $\mathrm{Zr}$ compared to the parent alloy substrate (since the $\mathrm{Al} / \mathrm{Zr}$ atomic ratio of the alloy of 0.5 was much smaller than 2). Interestingly, only the surface region of the oxide layer (up to a sputter depth of about 3 $\mathrm{nm}$ ) showed the composition $\left(\mathrm{Al}_{0.68} \mathrm{Zr}_{0.32}\right) \mathrm{O}_{1.66}$, corresponding to the expected $\mathrm{Al}^{\mathrm{ox}} / \mathrm{Zr}^{\mathrm{ox}}$ ratio of $\sim 2$ (i.e. matching that of the alloy surface), as shown in Fig. $4 \mathrm{~d}-\mathrm{f}$. The surface region showing a deviating composition can likely be rationalised by the original passive oxide layer, 
which formed spontaneously on the polished am- $\mathrm{Al}_{68 \mathrm{at} . \%} \mathrm{Zr}_{32}$ at.\% surface upon exposure to ambient conditions. Within the studied oxidation temperature range, extensive dissolution and inward diffusion of oxygen into the $\mathrm{c}-\mathrm{Al}_{2} \mathrm{Zr}$ and $\mathrm{am}-\mathrm{Al}_{68 \mathrm{at} . \%} \mathrm{Zr}_{32}$ at.\% [14] substrates did not occur owing to the relatively higher content of $\mathrm{Al}[38]$ (Fig. 4).

$\mathrm{Au}$ marker experiments were conducted for the oxidation of $\mathrm{c}-\mathrm{Al}_{2} \mathrm{Zr}$ and am-Al 68 at.\% $\mathrm{Zr}_{32 \text { at.\% }}$ at $400{ }^{\circ} \mathrm{C}$ for $10 \mathrm{~h}$ by AES depth profiling (Fig. 5). For both alloys, the pre-deposited ultra-thin (nominal thickness: $\sim 2 \mathrm{~nm}$ ) inert Au markers remained on the outer oxide surface instead of being buried in the thickening oxide layer. This suggests that oxide layer growth occurred mainly at the interface between the developing oxide layer and the parent alloy through inward diffusion of oxygen anions (with concurrent outward diffusion of anion vacancies, which were generated at the oxide/alloy interface by continuous dissolution of $\mathrm{O}$ into the alloy), in accordance with the oxidation mechanism for pure $\mathrm{Zr}$ metal as proposed previously $[40,41]$.

\subsection{Oxidation kinetics}

The oxide layer growth curves demonstrating the growth of the amorphous oxide layers on

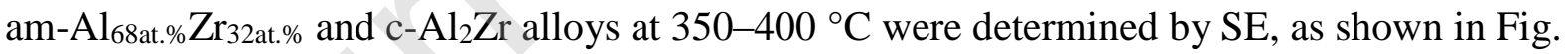
6a and Fig. 6b, respectively. The layer thicknesses determined by SE agreed well with those determined by TEM.

The oxidation kinetics of the $\mathrm{c}-\mathrm{Al}_{2} \mathrm{Zr}$ alloy was seen to follow a linear rate law (Fig. 6b) according to the following equation:

$$
d(t)=K_{1} t+d_{0}(T)
$$

where $d$ is the oxide layer thickness, $t$ is the oxidation time, $K_{1}$ is the linear growth rate 
constant, and $d_{0}(T)$ is introduced here to account for the combined effects of the native oxide and an initial, very fast oxidation stage (before the formation of a laterally-closed oxide layer at the alloy surface) $[26,42]$. The linear oxide growth indicated that the oxidation rate was limited by the reaction steps at the oxide surface or the alloy/oxide interface, presumably either the dissociative chemisorption of oxygen molecules at the oxide surface or the dissolution of oxygen from the oxide into the parent alloy at the alloy/oxide interface, respectively. The experimentally determined $K_{1}$ values were $2.4 \times 10^{-13}, 3.9 \times 10^{-13}$, and $6.6 \times 10^{-13} \mathrm{~m} / \mathrm{s}$ at 350,375 , and $400{ }^{\circ} \mathrm{C}$, respectively.

On the contrary, the oxidation kinetics of am- $\mathrm{Al}_{68 \mathrm{at} . \%} \mathrm{Zr}_{32 \mathrm{at} . \%}$ did not follow a linear growth law, but instead followed a parabolic rate law [29], characteristic for a diffusion rate-limited process, according to the following equation:

$$
d(t)=\sqrt{2 K_{\mathrm{p}} t+d_{0}(T)^{2}}
$$

where $K_{\mathrm{p}}$ is the parabolic growth-rate constant. Notably, the linear oxidation rate of the c- $\mathrm{Al}_{2} \mathrm{Zr}$ alloy was, on average, much higher than the (parabolic) oxidation rate of am-Al 68 at.\% $\mathrm{Zr}_{32 \text { at.\% }}$ alloy at the same temperature (Fig. 6), i.e. $d\left(\mathrm{c}-\mathrm{Al}_{2} \mathrm{Zr}\right)>$

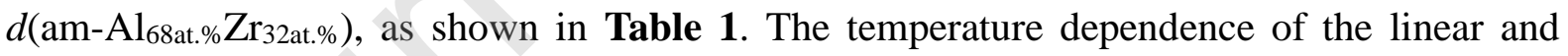
parabolic growth rate constants should typically follow an Arrhenius temperature dependence [43], according to the equation

$$
K(T)=K_{0} \exp \left(-\frac{Q}{\mathrm{R} \cdot T}\right)
$$

where $K_{0}$ is a pre-exponential factor, $Q$ is the effective activation energy of the rate-limiting reaction step(s), $\mathrm{R}$ is the gas constant, and $T$ is the oxidation temperature. The effective activation energy, $Q$, pertaining to the rate-limiting reaction step(s) of the oxidation process, 
could be determined by least-squares fitting of the series of growth curves of each alloy over the studied oxidation temperatures (Table 1). In the rate-controlling step of the oxidation process, the values of $Q$ were similar for $\mathrm{c}-\mathrm{Al}_{2} \mathrm{Zr}(Q=70 \mathrm{~kJ} / \mathrm{mol}=0.73 \mathrm{eV})$ and

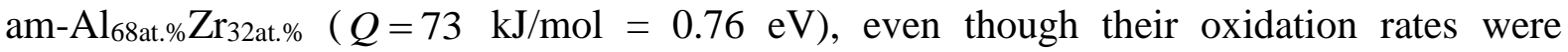
distinctly different.

\section{Discussion}

\subsection{Developing oxide microstructure}

An ultrathin (thickness $<5 \mathrm{~nm}$ ) passive oxide film spontaneously formed on $\mathrm{c}-\mathrm{Al}_{2} \mathrm{Zr}$ and am- $\mathrm{Al}_{68 \mathrm{at} . \%} \mathrm{Zr}_{32 \mathrm{at} . \%}$ upon exposure of the as-prepared alloy surfaces to the ambient atmosphere (prior to oxidation). The initial oxidation associated with the formation of the passive oxide is extremely fast, while atomic mobility in the alloy substrate at room temperature is practically negligible. Then, since $\mathrm{Al}$ and $\mathrm{Zr}$ show similar oxygen affinities, oxygen in the air reacts spontaneously with $\mathrm{Zr}$ and $\mathrm{Al}$ at the alloy (sub)surface to form an oxide with the same $\mathrm{Zr} / \mathrm{Al}$ ratio $(=2)$ as the parent $\mathrm{c}-\mathrm{Al}_{2} \mathrm{Zr}$ and am- $\mathrm{Al}_{68 a \mathrm{at}} \% \mathrm{Zr}_{32 \text { at. } \%}$ substrates, as observed in the present study.

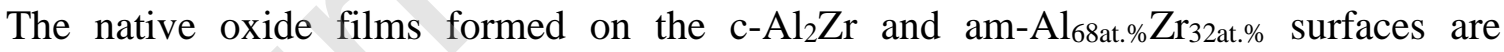
predominantly amorphous, which is thermodynamically preferred due to the relatively low surface and interface energies of the amorphous oxide state (compared to those of the corresponding crystalline oxide state) $[44,45]$. On the contrary, the amorphous state of the thermally grown oxide layers (thicknesses: $7-37 \mathrm{~nm}$ ) on both alloys at $350-400{ }^{\circ} \mathrm{C}$ is only metastable; the transformation from amorphous to crystalline state, with a lower (bulk) energy, is kinetically hindered at these intermediate temperatures owing to the large 
nucleation barrier for crystallization. The decomposition and crystallization of the amorphous $(\mathrm{Zr}, \mathrm{Al}, \mathrm{O})$ oxides into their competing crystalline $\mathrm{Al}_{2} \mathrm{O}_{3}$ and/or $\mathrm{ZrO}_{2}$ phases (note that crystalline $\mathrm{Al}_{2} \mathrm{O}_{3}$ and crystalline $\mathrm{ZrO}_{2}$ are not mutually soluble) requires sufficient atomic mobility in the oxide to form stable nuclei of the competing crystalline oxide phases. In addition, phase separation of the amorphous ternary oxide into two new crystalline phases will involve energy penalties associated with $(i)$ the creation of new interfaces between the product phase and its surrounding matrix ( $\Delta G_{\text {interface }}$ ), as well as (ii) the generation of elastic strain energy due to the huge volume mismatch between the parent and product phases ( $\left.\Delta G_{\text {strain }}\right)$. Consequently, relatively high temperatures are required to crystallize the amorphous (Zr,Al) oxide phases (e.g. about $T>800 \mathrm{~K}$ for amorphous (Zr,Al)-oxide layers on am-Al 68 at.\% $\mathrm{Zr}_{32 \mathrm{at} . \%)}$ [24].

\subsection{Oxidation mechanism}

The $\mathrm{c}-\mathrm{Al}_{2} \mathrm{Zr}$ and am- $\mathrm{Al}_{68 \text { at. } \%} \mathrm{Zr}_{32 \text { at. } \%}$ have practically identical chemical compositions but exhibit distinct differences in their oxidation behaviours, which highlights the vital role of structural order in the parent alloy in determining the oxidation mechanism. Thermal

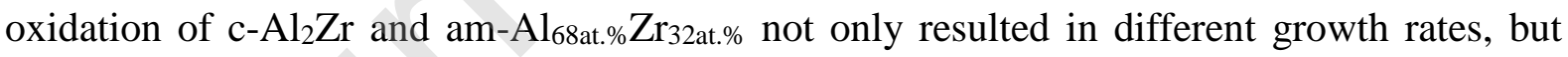
also led to distinctly different compositions of the amorphous oxide overlayers: i.e. $\left(\mathrm{Al}_{0.68} \mathrm{Zr}_{0.32}\right) \mathrm{O}_{1.66}$ and $\left(\mathrm{Al}_{0.33} \mathrm{Zr}_{0.67}\right) \mathrm{O}_{1.83}$ for the oxidation of c- $\mathrm{Al}_{2} \mathrm{Zr}$ and am- $\mathrm{Al}_{68 \text { at.\%}} \mathrm{Zr}_{32 \mathrm{at} . \%}$ alloy, respectively.

As indicated by the Au marker experiments, growth of the amorphous oxide layers on both alloys proceeds by inward diffusion of oxygen with the formation of new oxide species at the oxide/alloy interface. Previous diffusion marker studies undertaken by Kai et al. [46], 
${ }^{18} \mathrm{O}_{2}$ isotopic tracer experiments conducted by Wang et al. [47] on $\mathrm{Zr}$-based metallic glasses, as well as a study by Prescott [40] on the oxidation of Al-based alloys confirmed oxygen diffusion-controlled oxidation of both Zr-based and Al-based alloys for the studied composition range.

The following processes can be rate-limiting for the oxidation of the crystalline $\mathrm{Al}_{2} \mathrm{Zr}$

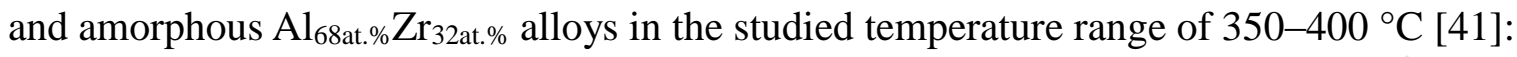

(i) O vacancy diffusion in the oxide lattice (resulting in a parabolic rate)

(ii) a surface (sub)reaction at the $\mathrm{O}_{2}(\mathrm{~g}) / \mathrm{oxide}$ interface (e.g. dissociative chemisorption or filling of $\mathrm{O}$ vacancies at the gas/oxide interface)

(iii) injection of $\mathrm{O}$ vacancies in the growing oxide layer by dissolution of oxygen into the alloy substrate at the oxide/alloy interface

Ad (i): The chemical diffusion coefficient of oxygen in bulk $\mathrm{ZrO}_{2}$ is typically much higher than that in bulk $\mathrm{Al}_{2} \mathrm{O}_{3}\left(3.2 \times 10^{-8} \mathrm{~m}^{2} / \mathrm{s}\right.$ for $\mathrm{ZrO}_{2}$ at $1000{ }^{\circ} \mathrm{C}[48]$ and $2.7 \times 10^{-14} \mathrm{~m}^{2} / \mathrm{s}$ for $\mathrm{Al}_{2} \mathrm{O}_{3}$ at $1000{ }^{\circ} \mathrm{C}$ [49]). It might then be naively assumed that oxygen diffusion and thus the oxidation rate in the amorphous $(\mathrm{Al}, \mathrm{Zr})$ oxide would be higher for a lower $\mathrm{Al}$ concentration in the mixed ( $\mathrm{Al}, \mathrm{Zr}$ ) oxide phase (i.e. a lower $\mathrm{Al}^{\mathrm{ox}} / \mathrm{Zr}^{\mathrm{ox}}$ ratio), provided the molar density of oxygen in the oxide remains approximately constant. The molar densities of oxygen, $D_{\mathrm{O}}$, in the am- $\left(\mathrm{Al}_{0.33} \mathrm{Zr}_{0.67}\right) \mathrm{O}_{1.83}$ and am- $\left(\mathrm{Al}_{0.68} \mathrm{Zr}_{0.32}\right) \mathrm{O}_{1.66}$ overlayers were estimated from the corresponding molar densities of amorphous $\mathrm{Al}_{2} \mathrm{O}_{3}$ [50] and $\mathrm{ZrO}_{2}$ [51] assuming average compositions of $\left(\mathrm{AlO}_{1.5}\right)_{0.33}\left(\mathrm{ZrO}_{2}\right)_{0.67}$ and $\left(\mathrm{AlO}_{1.5}\right)_{0.68}\left(\mathrm{ZrO}_{2}\right)_{0.32}$, respectively (Table 2). The estimated oxygen molar densities observed for am- $\left(\mathrm{Al}_{0.68} \mathrm{Zr}_{0.32}\right) \mathrm{O}_{1.66}$ oxide on $\mathrm{c}-\mathrm{Zr}_{2} \mathrm{Al}$ and am- $\left(\mathrm{Al}_{0.33} \mathrm{Zr}_{0.67}\right) \mathrm{O}_{1.83}$ oxide on am- $\mathrm{Al}_{68 \text { at. } \%} \mathrm{Zr}_{32 \mathrm{at} . \%}$ were $9.103 \times 10^{4}$ and $9.228 \times 10^{4} \mathrm{~mol} / \mathrm{m}^{3}$, 
respectively, which are very similar. This suggests that the oxygen chemical diffusion coefficient in the $\mathrm{Al}$-enriched am- $\left(\mathrm{Al}_{0.68} \mathrm{Zr}_{0.32}\right) \mathrm{O}_{1.66}$ oxide (with $\mathrm{Al}^{\mathrm{ox}} / \mathrm{Zr}^{\mathrm{ox}}$ ratio $=2$ ) on the c- $\mathrm{Al}_{2} \mathrm{Zr}$ alloy should be lower than that in the $\mathrm{Zr}$-enriched am- $\left(\mathrm{Al}_{0.33} \mathrm{Zr}_{0.67}\right) \mathrm{O}_{1.83}$ oxide (with

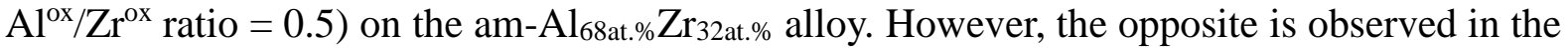
present study (i.e. the oxidation rate is much faster for the $\mathrm{c}-\mathrm{Al}_{2} \mathrm{Zr}$ alloy with the Al-rich oxide overlayer): see Fig. 6. Moreover, the oxidation kinetics for the $\mathrm{c}_{-} \mathrm{Al}_{2} \mathrm{Zr}$ alloy follow a linear growth law, whereas a parabolic growth law would be expected for oxygen diffusion-controlled growth. Hence the hypothesis that the oxidation of both alloys is rate-limited by the chemical diffusion of oxygen in the oxide can be ruled out.

Ad (ii): If the oxidation would be rate-limited by a reaction rate at the oxide surface (e.g. dissociative chemical adsorption), the growth kinetics of the amorphous oxide overlayer would proceed at a similar, linear rate for both alloys, since the surface compositions of the oxide layers are practically identically (as determined by the stage of passive oxide film formation prior to thermal oxidation: see Section 4.1). This is not the case in this work.

Ad (iii): Oxygen lattice transport through the thickening oxide layers requires coupled fluxes of inwardly migrating oxygen anions and outwardly migrating $\mathrm{O}$ vacancies (as coupled to diffusion fluxes of electrons and electron holes). In this case, $\mathrm{O}$ vacancies are generated by oxygen dissolution at the alloy/oxide interface and are subsequently injected into the growing oxide layer. The dissolved oxygen in the alloy may diffuse from the alloy/oxide interface into the interior of the parent alloy and/or locally reach a critical concentration to nucleate an oxide. Such oxygen dissolution and, particularly, oxygen inward diffusion will be affected by the atomic arrangement in the parent alloy. For example, as demonstrated by Bakradze et al. 
[42], for single-crystalline $\alpha-Z r$, the less densely packed $\operatorname{Zr}(10 \overline{1} 0)$ surface oxidizes more rapidly than the densely packed $\operatorname{Zr}(0001)$ surface, which can be attributed to the anisotropy of the oxygen diffusion coefficient in the hcp structure (the oxygen diffusivities are $D_{\text {basal }}=2.4 \times 10^{-21} \mathrm{~m}^{2} / \mathrm{s}$ and $D_{\text {prism }}=4.8 \times 10^{-21} \mathrm{~m}^{2} / \mathrm{s}$ for $\alpha-\mathrm{Zr}$ at $T=450 \mathrm{~K}$, respectively).

The diffusivities of oxygen in the $\mathrm{c}-\mathrm{Al}_{2} \mathrm{Zr}$ and am- $\mathrm{Al}_{68 \mathrm{at} . \%} \mathrm{Zr}_{32 \text { at. } \%}$ alloys were estimated by MD simulations. The diffusion coefficient $D$ was determined as follows: [52]

$$
D=\frac{<R^{2}(t)>}{6 t}
$$

where $\left\langle R^{2}(t)\right\rangle$ is the mean square displacement (MSD) of diffusing atoms and $t$ is the simulation time. Derived from the slopes of the fitted line of MSD against $t$ (Fig. 7), the ratios

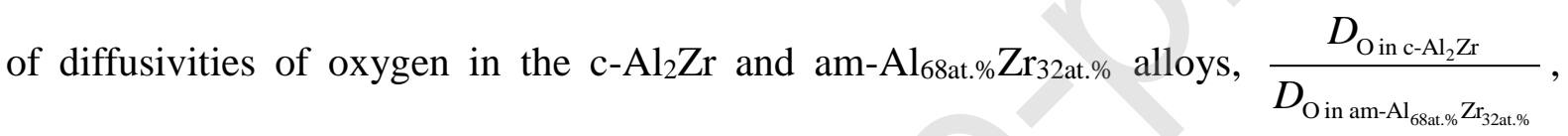
were 1.44 at $350{ }^{\circ} \mathrm{C}, 1.64$ at $375^{\circ} \mathrm{C}$, and 1.16 at $400{ }^{\circ} \mathrm{C}$, respectively, which indeed confirms

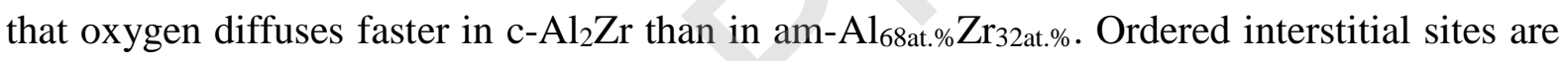
only present in the $\mathrm{c}-\mathrm{Al}_{2} \mathrm{Zr}$ alloy (and are absent in the am- $\mathrm{Al}_{68 \text { at.\%}} \mathrm{Zr}_{32 \mathrm{at} . \%}$ alloy); these ordered interstitial sites enable fast oxygen migration in the crystalline alloy matrix, which in turn results in a relatively high injection rate of $\mathrm{O}$ vacancies in the developing oxide at the reaction front (i.e. the alloy/oxide interface). Due to the absence of long-range order, am- $\mathrm{Al}_{68 \mathrm{at} . \%} \mathrm{Zr}_{32 \mathrm{at} . \%}$ does not provide any well-defined, energetically-favourable interstitial sites pathways for inward diffusion of $\mathrm{O}$ (as is the case for $\mathrm{c}-\mathrm{Al}_{2} \mathrm{Zr}$ ). Consequently, the rate of oxygen dissolution and therefore the injection rate of oxygen vacancies into the growing layer are suppressed, resulting in the observed decrease in the oxidation rate for

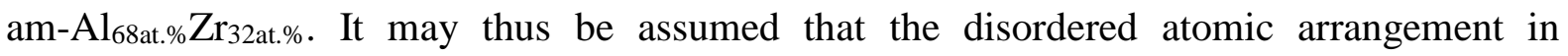


am- $\mathrm{Al}_{68 \text { at. } \%} \mathrm{Zr}_{32 \text { at. } \%}$ retards not only the oxygen dissolution at the alloy/oxide interface, but

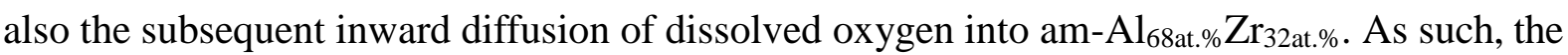
generation of available sites for oxygen dissolution into am- $\mathrm{Al}_{68 \text { at.\%}} \mathrm{Zr}_{32 \text { at.\% }}$ is partially blocked by the retarded inward diffusion rate of oxygen into am-Al 68 at.\% $\mathrm{Zr}_{32 \text { at.\%, which would }}$ also explain the observed parabolic oxidation kinetics (characteristic for a diffusion-controlled reaction rate) see also Section 3.3.

\subsection{Developing oxide composition}

The am- $\left(\mathrm{Al}_{0.33} \mathrm{Zr}_{0.67}\right) \mathrm{O}_{1.83}$ phase with a $\mathrm{Al}^{3+} / \mathrm{Zr}^{4+}$ ratio of about 0.5 , which formed on the oxidized am- $\mathrm{Al}_{68 \text { at.\% }} \mathrm{Zr}_{32 \mathrm{at} . \%}$ alloy, corresponds to the lowest Gibbs energy of formation, $\Delta G$, for the $\mathrm{Al}_{2} \mathrm{O}_{3}-\mathrm{ZrO}_{2}$ pseudo binary system (i.e. the lowest enthalpy of mixing of am- $-\mathrm{Al}_{2} \mathrm{O}_{3}$ and am- $\mathrm{ZrO}_{2}$ ) and is thus thermodynamically preferred, as discussed in detail previously [14]. The oxide layer formed on $\mathrm{c}-\mathrm{Al}_{2} \mathrm{Zr}$ is also amorphous, but shows a very different composition of am- $\left(\mathrm{Al}_{0.68} \mathrm{Zr}_{0.32}\right) \mathrm{O}_{1.66}$, corresponding to an $\mathrm{Al}^{3+} / \mathrm{Zr}^{4+}$ ratio of about 2 , which is the same as that of the $\mathrm{c}-\mathrm{Al}_{2} \mathrm{Zr}$ substrate. The am- $\left(\mathrm{Al}_{0.68} \mathrm{Zr}_{0.32}\right) \mathrm{O}_{1.66}$ layer can be formed on the $\mathrm{c}-\mathrm{Al}_{2} \mathrm{Zr}$ alloy at temperatures as high as $750{ }^{\circ} \mathrm{C}$ [53]. The question arises if the formation of the am- $\left(\mathrm{Al}_{0.68} \mathrm{Zr}_{0.32}\right) \mathrm{O}_{1.66}$ phase on the $\mathrm{c}-\mathrm{Al}_{2} \mathrm{Zr}$ alloy can also be rationalized on the basis of thermodynamics or if it has a kinetic origin.

As discussed in Section 4.2, it may be assumed that oxygen diffusion through $h$ and $t$ interstitial sites into the ordered hexagonal lattice of $\mathrm{c}-\mathrm{Al}_{2} \mathrm{Zr}$ is much faster than oxygen

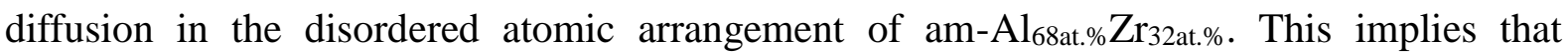
oxygen can easily diffuse to and distribute between energetically favourable interstices in the c- $\mathrm{Al}_{2} \mathrm{Zr}$ lattice to form an amorphous $(\mathrm{Al}, \mathrm{Zr})$ oxide phase with a stoichiometric $\mathrm{Al} / \mathrm{Zr}$ ratio, 
which is equivalent to that of the original $c-\mathrm{Al}_{2} \mathrm{Zr}$ unit cell (i.e. $\mathrm{Al} / \mathrm{Zr}=2$ ). Hence, no substantial diffusion or exchange of $\mathrm{Al}$ and $\mathrm{Zr}$ atoms in the $\mathrm{c}-\mathrm{Al}_{2} \mathrm{Zr}$ lattice is necessary for continuing the oxide layer growth. Due to the fast diffusion of oxygen and relative immobilization of the $\mathrm{Al}$ and $\mathrm{Zr}$ atoms in the crystal lattices, the $\mathrm{Al}^{3+} / \mathrm{Zr}^{4+}$ ratio in the oxide layer formed on the $\mathrm{Al}_{2} \mathrm{Zr}$ alloy was almost the same as that of the substrate. As indicated by the Arrhenius analysis of the oxidation kinetics in Section 3.3, the rate-limiting step of the oxidation process was the dissolution of oxygen into $\mathrm{c}-\mathrm{Al}_{2} \mathrm{Zr}$ at the migrating reaction front (i.e. the oxide/alloy interface) and not the diffusion of oxygen in c- $\mathrm{Al}_{2} \mathrm{Zr}$.

As discussed in Section 4.2, both oxygen dissolution and oxygen diffusion are hindered

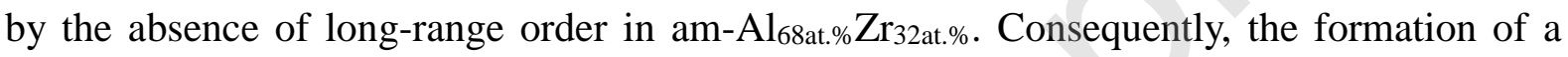
compositionally homogenous region in am- $\mathrm{Al}_{68 a t . \%} \mathrm{Zr}_{32 \mathrm{at} . \%}$ (i.e. with a constant elemental distribution of $\mathrm{Al}, \mathrm{Zr}$, and $\mathrm{O}$ on a local scale) not only requires a certain atomic mobility of oxygen in the alloy, but also necessitates specific atomic arrangements of $\mathrm{Al}$ and $\mathrm{Zr}$ (note: the mobility of $\mathrm{Al}$ in the alloy is likely higher than that of $\mathrm{Zr}$ [29]). Consequently, the rate of oxide formation in the am- $\mathrm{Al}_{68 a t . \%} \mathrm{Zr}_{32}$ at.\% alloy is significantly suppressed in comparison with that in the $\mathrm{c}-\mathrm{Al}_{2} \mathrm{Zr}$ alloy. Local redistribution of $\mathrm{O}, \mathrm{Al}$, and $\mathrm{Zr}$ (i.e. local chemical fluctuations) are required to form a stable critical nucleus size for the thermodynamically preferred am- $\left(\mathrm{Al}_{0.33} \mathrm{Zr}_{0.67}\right) \mathrm{O}_{1.83}$ phase with a $\mathrm{Al}^{3+} / \mathrm{Zr}^{4+}$ ratio of about 0.5 [14]. Consequently, parabolic oxidation kinetics could be observed (Section 3.3), which is characteristic of a diffusion-controlled oxidation process.

\section{Conclusions}

- The oxidation of amorphous and crystalline Al-Zr binary alloys has been investigated on 
a comparative basis to disclose the effect of structural order on the underlying oxidation mechanism of metallic alloys.

- An amorphous oxide phase with a well-defined stoichiometric composition of $\left(\mathrm{Al}_{0.68} \mathrm{Zr}_{0.32}\right) \mathrm{O}_{1.66}$ formed on the crystalline $\mathrm{Al}_{2} \mathrm{Zr}$ alloy at $350-400{ }^{\circ} \mathrm{C}$, in striking contrast with the formation of an $\left(\mathrm{Al}_{0.33} \mathrm{Zr}_{0.67}\right) \mathrm{O}_{1.83}$ amorphous oxide on the amorphous $\mathrm{Al}_{68 a t . \%} \mathrm{Zr}_{32 \text { at.\% }}$ alloy. The oxidation kinetics of crystalline $\mathrm{Al}_{2} \mathrm{Zr}$ alloy was fast and linear, distinctively different from the slow, parabolic oxidation kinetics of the amorphous

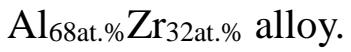

- Based on molecular dynamics simulations, the pronounced role of structural (dis)order of the parent alloy in determining the oxidation behaviour has been disclosed. In the crystalline $\mathrm{Al}_{2} \mathrm{Zr}$ alloy, rapid oxygen diffusion along the diffusion path composed of energetically favourable interstitial sites results in fast oxidation kinetics due to the increased rate of injection of $\mathrm{O}$ vacancies in the developing oxide at the alloy/oxide interface. On the contrary, oxygen dissolution and diffusion are impeded by the long-range disorder in the amorphous counterpart, resulting in significantly lowered oxidation kinetics.

- The oxide composition on the crystalline $\mathrm{Al}_{2} \mathrm{Zr}$ alloy is dictated by kinetics: due to the fast diffusion of oxygen and relative immobilization of $\mathrm{Al}$ and $\mathrm{Zr}$ atoms in the crystal lattices, the $\mathrm{Al}^{3+} / \mathrm{Zr}^{4+}$ ratio $(\approx 2)$ in the oxide layer formed on the $\mathrm{Al}_{2} \mathrm{Zr}$ alloy is practically the same as that in the substrate. On the contrary, the oxide composition of the amorphous alloy is thermodynamically controlled: oxygen dissolution and inward diffusion in the amorphous alloy are retarded by the structural disorder. The required 
sluggish re-arrangements of $\mathrm{Al}$ and $\mathrm{Zr}$ atoms result in a thermodynamically preferred oxide composition of $\left(\mathrm{Al}_{0.33} \mathrm{Zr}_{0.67}\right) \mathrm{O}_{1.83}\left(\mathrm{Al}^{3+} / \mathrm{Zr}^{4+} \approx 0.5\right)$.

- The above findings provide compelling evidences on the intrinsic role of structural order of parent alloys in governing the oxidation kinetics and the evolving oxide phase composition, thus offering a new perspective in the field of surface engineering.

author statement

Yifei Xu: Investigation, Visualization, Writing - Original Draft.

Lars P. H. Jeurgens: Conceptualization, Writing - Review \& Editing.

Yuan Huang: Software.

Chong Li: Resource.

Yongchang Liu: Project administration.

Zumin Wang: Conceptualization, Writing - Review \& Editing, Funding acquisition.

\section{Declaration of interests}

The authors declare that they have no known competing financial interests or personal relationships that could have appeared to influence the work reported in this paper

\section{Data availability statement}

All data included in this study are available upon request by contact with the corresponding author.

\section{Acknowledgements}

This work was supported by the National Natural Science Foundation of China (No. 
51571148), the National Key Research and Development Program of China (No.

2017YFE0302600 and No. 2017YFB0701801), and the Thousand Talents Program for

Distinguished Young Scholars of China.

\section{References}

[1] H. Over, A.P. Seitsonen, Oxidation of Metal Surfaces, Science, 297 (2002) 2003-2005.

[2] N. Birks, G.H. Meier, F.S. Pettit, Introduction to the High Temperature Oxidation of Metals, Cambridge University Press, Cambridge, 2006.

[3] K. Takada, H. Sakurai, E. Takayama-Muromachi, F. Izumi, R.A. Dilanian, T. Sasaki, Superconductivity in two-dimensional $\mathrm{CoO}_{2}$ layers, Nature, 422 (2003) 53-55.

[4] K.Y. Frolenkov, L.Y. Frolenkova, I.F. Shadrin, High-temperature oxidation of low-alloyed steel under glass coatings, Protection of Metals and Physical Chemistry of Surfaces, 46 (2010) 103-109.

[5] J.S. Park, W.J. Maeng, H.S. Kim, J.S. Park, Review of recent developments in amorphous oxide semiconductor thin-film transistor devices, Thin Solid Films, 520 (2012) 1679-1693.

[6] P. Huczkowski, S.G. Gopalakrishnan, W. Nowak, H. Hattendorf, R. Iskandar, J. Mayer, W.J. Quadakkers, Effect of Zr Content on the Morphology and Emissivity of Surface Oxide Scales on FeCrAlY Alloys Adv. Eng. Mater., 18 (2016) 711-720.

[7] T. Huang, D. Naumenko, P. Song, J. Lu, W.J. Quadakkers, Effect of Titanium Addition on Alumina Growth Mechanism on Yttria-Containing FeCrAl-Base Alloy, Oxidation of Metals, 90 (2018) 671-690.

[8] L. Boatemaa, M. Bosch, A.S. Farle, G.P. Bei, S. van der Zwaag, W.G. Sloof, Autonomous high-temperature healing of surface cracks in $\mathrm{Al}_{2} \mathrm{O}_{3}$ containing $\mathrm{Ti}_{2} \mathrm{AlC}$ particles, Journal of the American Ceramic Society, 101 (2018) 5684-5693.

[9] L.P.H. Jeurgens, W.G. Sloof, F.D. Tichelaar, E.J. Mittemeijer, Thermodynamic stability of amorphous oxide films on metals: Application to aluminum oxide films on aluminum substrates, Physical Review B, 62 (2000) 4707-4719.

[10] F. Reichel, L.P.H. Jeurgens, E.J. Mittemeijer, Thermodynamic model of oxide overgrowth on bare metals: Relaxation of growth strain by plastic deformation, Physical Review B, 74 (2006).

[11] F. Reichel, L.P.H. Jeurgens, G. Richter, P.A. van Aken, E.J. Mittemeijer, The origin of high-mismatch orientation relationships for ultra-thin oxide overgrowths, Acta Materialia, 55 (2007) 6027-6037. 
[12] F. Reichel, L.P.H. Jeurgens, E.J. Mittemeijer, The thermodynamic stability of amorphous oxide overgrowths on metals, Acta Materialia, 56 (2008) 659-674.

[13] E. Panda, L.P.H. Jeurgens, E.J. Mittemeijer, Interface thermodynamics of ultra-thin, amorphous oxide overgrowths on AlMg alloys, Acta Materialia, 58 (2010) 1770-1781.

[14] K. Weller, Z.M. Wang, L.P.H. Jeurgens, E.J. Mittemeijer, Thermodynamics controls amorphous oxide formation: Exclusive formation of a stoichiometric amorphous $\left(\mathrm{Al}_{0.33} \mathrm{Zr}_{0.67}\right) \mathrm{O}_{1.83}$ phase upon thermal oxidation of $\mathrm{Al}-\mathrm{Zr}$, Acta Materialia, 94 (2015) 134-142.

[15] Z. Xu, Y. Xu, A. Zhang, J. Wang, Z. Wang, Oxidation of amorphous alloys, Journal of Materials Science \& Technology, 34 (2018) 1977-2005.

[16] K. Manwani, A.J. Chelvane, E. Panda, Oxidation of $\mathrm{TbFe}_{2}$ : Microstructure of oxide-film by both theory and experiment, Corros. Sci., 130 (2018) 153-160.

[17] P. Thurnheer, F. Haag, J.F. Löffler, Time-resolved measurement of shear-band temperature during serrated flow in a Zr-based metallic glass, Acta Materialia, 115 (2016) 468-474.

[18] K.J. Laws, D. Granata, J.F. Löffler, Alloy design strategies for sustained ductility in Mg-based amorphous alloys - Tackling structural relaxation, Acta Materialia, 103 (2016) 735-745.

[19] D. Flötotto, Z.M. Wang, L.P.H. Jeurgens, E.J. Mittemeijer, Intrinsic stress evolution during amorphous oxide film growth on Al surfaces, Appl Phys Lett, 104 (2014) 091901.

[20] J. Qiao, H. Jia, P.K. Liaw, Metallic glass matrix composites, Materials Science and Engineering: R: Reports, 100 (2016) 1-69.

[21] K. Weller, T. Suter, Z.M. Wang, L.P.H. Jeurgens, E.J. Mittemeijer, The effect of pre-oxidation treatment on the corrosion behavior of amorphous $\mathrm{Al}_{1-x} \mathrm{Zr}_{x}$ solid-solution alloys, Electrochimica Acta, 188 (2016) 31-39.

[22] Y.S. Jung, J.Y. Seo, D.W. Lee, D.Y. Jeon, Influence of DC magnetron sputtering parameters on the properties of amorphous indium zinc oxide thin film, Thin Solid Films, 445 (2003) 63-71.

[23] L. Zeng, D.T. Tran, C.-W. Tai, G. Svensson, E. Olsson, Atomic structure of the ultrathin amorphous aluminium oxide barrier in $\mathrm{Al} / \mathrm{AlO}_{\mathrm{x}} / \mathrm{Al}$ Josephson junctions, in: European Microscopy Congress 2016: Proceedings, 2016.

[24] K. Weller, L.P.H. Jeurgens, Z. Wang, E.J. Mittemeijer, Thermal oxidation of amorphous $\mathrm{Al}_{0.44} \mathrm{Zr}_{0.56}$ alloys, Acta Materialia, 87 (2015) 187-200.

[25] L. Jastrow, U. Köster, Oxidation of amorphous $\mathrm{Zr}_{70} \mathrm{Pd}_{30}$ and coarse crystalline $\mathrm{Zr}_{2} \mathrm{Pd}$, MRS Proceedings, 806 (2004) MM10.61-MM10.66.

[26] T.J. Nijdam, L.P.H. Jeurgens, W.G. Sloof, Effect of partial oxygen pressure on the initial 
stages of high-temperature oxidation of $\gamma-\mathrm{NiCrAl}$ alloys, Materials at High Temperatures, 20 (2003) 311-318.

[27] A. Szekeres, P. Danesh, Oxidation of amorphous and crystalline silicon, Journal of Non-Crystalline Solids, 187 (1995) 45-48.

[28] M. Miyasaka, W. Itoh, H. Ohshima, T. Shimoda, Dry thermal oxidation of polycrystalline and amorphous silicon films for application to thin film transistors, Japanese Journal of Applied Physics Part 1-Regular Papers Short Notes \& Review Papers, 37 (1998) 1076-1081.

[29] K. Weller, Z.M. Wang, L.P.H. Jeurgens, E.J. Mittemeijer, Oxidation kinetics of amorphous $\mathrm{Al}_{x} \mathrm{Zr}_{1-x}$ alloys, Acta Materialia, 103 (2016) 311-321.

[30] H. Yao, C.H. Yan, Anisotropic optical responses of sapphire $\left(\alpha-\mathrm{Al}_{2} \mathrm{O}_{3}\right)$ single crystals, Journal of Applied Physics, 85 (1999) 6717-6722.

[31] P. Petrik, T. Gumprecht, A. Nutsch, G. Roeder, M. Lemberger, G. Juhasz, O. Polgar, C. Major, P. Kozma, M. Janosov, B. Fodor, E. Agocs, M. Fried, Comparative measurements on atomic layer deposited $\mathrm{Al}_{2} \mathrm{O}_{3}$ thin films using ex situ table top and mapping ellipsometry, as well as X-ray and VUV reflectometry, Thin Solid Films, 541 (2013) 131-135.

[32] R.H. French, S.J. Glass, F.S. Ohuchi, Y.N. Xu, W.Y. Ching, Experimental and theoretical determination of the electronic structure and optical properties of three phases of $\mathrm{ZrO}_{2}$, Physical Review B, 49 (1994) 5133-5142.

[33] A. Lyapin, L.P.H. Jeurgens, P.C.J. Graat, E.J. Mittemeijer, Ellipsometric and XPS study of the initial oxidation of zirconium at room temperature, Surface and Interface Analysis, 36 (2004) 989-992.

[34] P. Petrik, A. Sulyok, T. Novotny, E. Perez-Feró, B. Kalas, E. Agocs, T. Lohner, D. Lehninger, L. Khomenkova, R. Nagy, J. Heitmann, M. Menyhard, Z. Hózer, Optical properties of $\mathrm{Zr}$ and $\mathrm{ZrO}_{2}$, Applied Surface Science, 421 (2017) 744-747.

[35] J. Ayache, L. Beaunier, J. Boumendil, G. Ehret, D. Laub, Sample Preparation Handbook for TEM, Springer, Berlin, 2010.

[36] A.K. Rappe, C.J. Casewit, K.S. Colwell, W.A. Goddard, W.M. Skiff, UFF, a full periodic table force field for molecular mechanics and molecular dynamics simulations, Journal of the American Chemical Society, 114 (1992) 10024-10035.

[37] S. Luo, J. Hao, Y. Gao, D. Liu, Q. Cai, X. Yang, Pore size effect on adsorption and release of metoprolol tartrate in mesoporous silica: Experimental and molecular simulation studies, Materials Science and Engineering: C, 100 (2019) 789-797.

[38] K. Weller, N. Zotov, Z.M. Wang, L.P.H. Jeurgens, E.J. Mittemeijer, Atomic structure, electronic structure and thermal stability of amorphous $\mathrm{Al}_{x} \mathrm{Zr}_{1-x}(0.26 \leq x \leq 0.75)$, Journal of Non-Crystalline Solids, 427 (2015) 104-113.

[39] J.E. Dennis, R.B. Schnabel, Chapter I A view of unconstrained optimization, in: 
Handbooks in Operations Research and Management Science, Elsevier, 1989, pp. 1-72.

[40] R. Prescott, M.J. Graham, The formation of aluminum oxide scales on high-temperature alloys, Oxidation of Metals, 38 (1992) 233-254.

[41] G. Bakradze, L.P.H. Jeurgens, T. Acarturk, U. Starke, E.J. Mittemeijer, Atomic transport mechanisms in thin oxide films grown on zirconium by thermal oxidation, as-derived from $\mathrm{O}^{18}$-tracer experiments, Acta Materialia, 59 (2011) 7498-7507.

[42] G. Bakradze, L.P.H. Jeurgens, E.J. Mittemeijer, The different initial oxidation kinetics of $\operatorname{Zr}(0001)$ and $\operatorname{Zr}(10-10)$ surfaces, Journal of Applied Physics, 110 (2011) 024904.

[43] Hauffe, High Temperature Oxidation of Metals. P. Kofstad John Wiley \& Son, New York 1966, 340 S, Materials and Corrosion, 18 (1967) 956-957.

[44] E. Panda, L.P.H. Jeurgens, G. Richter, E.J. Mittemeijer, The amorphous to crystalline transition of ultrathin ( $\mathrm{Al}, \mathrm{Mg}$ )-oxide films grown by thermal oxidation of $\mathrm{AlMg}$ alloys: A high-resolution transmission electron microscopy investigation, Journal of Materials Research, 25 (2010) 871-879.

[45] Y. Xu, X. Liu, L. Gu, J. Wang, P. Schützendübe, Y. Huang, Y. Liu, Z. Wang, Natural oxidation of amorphous $\mathrm{Cu}_{x} \mathrm{Zr}_{1-x}$ alloys, Applied Surface Science, 457 (2018) 396-402.

[46] W. Kai, H.H. Hsieh, T.G. Nieh, Y. Kawamura, Oxidation behavior of a Zr-Cu-Al-Ni amorphous alloy in air at 300-425 ${ }^{\circ} \mathrm{C}$, Intermetallics, 10 (2002) 1265-1270.

[47] B. Wang, D.Y. Huang, N. Prud'homme, Z. Chen, F. Jomard, T. Zhang, V. Ji, Diffusion mechanism of Zr-based metallic glass during oxidation under dry air, Intermetallics, 28 (2012) 102-107.

[48] F.J. Keneshea, D.L. Douglass, The diffusion of oxygen in Zirconia as a function of oxygen pressure, Oxidation of Metals, 3 (1971) 1-14.

[49] Y. Olshi, W.D. Klngery, Self-diffusion of oxygen in single crystal and polycrystalline aluminum oxide, Journal of Chemical Physics, 33 (1960) 480-486.

[50] G. Gutiérrez, B. Johansson, Molecular dynamics study of structural properties of amorphous $\mathrm{Al}_{2} \mathrm{O}_{3}$, Physical Review B, 65 (2002) 104202.

[51] X. Zhao, D. Ceresoli, D. Vanderbilt, Structural, electronic, and dielectric properties of amorphous $\mathrm{ZrO}_{2}$ from ab initio molecular dynamics, Physical Review B, 71 (2005) 085107.

[52] B. Lee, B. Lee, A Comparative Study on Hydrogen Diffusion in Amorphous and Crystalline Metals Using a Molecular Dynamics Simulation, Metallurgical and Materials Transactions A, 45 (2014) 2906-2915.

[53] Z. Hu, Y. Xu, Y. Chen, P. Schützendübe, J. Wang, Y. Huang, Y. Liu, Z. Wang, Anomalous formation of micrometer-thick amorphous oxide surficial layers during high-temperature oxidation of $\mathrm{ZrAl}_{2}$, Journal of Materials Science \& Technology, 35 (2019) 1479-1484. 


\section{Table 1}

Oxide layer growth parameters for $\mathrm{c}-\mathrm{Al}_{2} \mathrm{Zr}$ and $\mathrm{am}-\mathrm{Al}_{68 \mathrm{at} . \%} \mathrm{Zr}_{32 a t . \%}$ alloys [29]: activation energy $Q$ and oxide layer thickness $d$ at $t=10 \mathrm{~h}$.

\begin{tabular}{cccccc}
\hline & & & \multicolumn{3}{c}{$d$ for $10 \mathrm{~h}(\mathrm{~nm})$} \\
Specimen & Mode & $Q(\mathrm{~kJ} / \mathrm{mol})$ & \multicolumn{3}{c}{} \\
& & & $350{ }^{\circ} \mathrm{C}$ & $375{ }^{\circ} \mathrm{C}$ & $400{ }^{\circ} \mathrm{C}$ \\
\hline $\mathrm{c}-\mathrm{Al}_{2} \mathrm{Zr}$ & linear & 70 & 14.9 & 24.3 & 33.1 \\
& & & & 11.0 & 15.9 \\
\hline
\end{tabular}

Table 2

Mass densities of materials investigated and molar oxygen densities of corresponding amorphous oxides [50, 51].

\begin{tabular}{ccc}
\hline Material & Mass Density $\left(\mathrm{g} / \mathrm{cm}^{3}\right)$ & Atomic Density $D_{\mathrm{O}}\left(10^{4} \mathrm{~mol} / \mathrm{m}^{3}\right)$ \\
\hline $\mathrm{am}-\mathrm{Al}_{2} \mathrm{O}_{3}$ & $3.175[50]$ & 9.342 \\
$\mathrm{am}-\mathrm{ZrO}_{2}$ & $5.537[51]$ & 8.986 \\
$\mathrm{am}-\left(\mathrm{Al}_{0.33} \mathrm{Zr}_{0.67}\right) \mathrm{O}_{1.83}$ & 4.758 & 9.103 \\
$\mathrm{am}-\left(\mathrm{Al}_{0.68} \mathrm{Zr}_{0.32}\right) \mathrm{O}_{1.66}$ & 3.931 & 9.228 \\
\hline
\end{tabular}




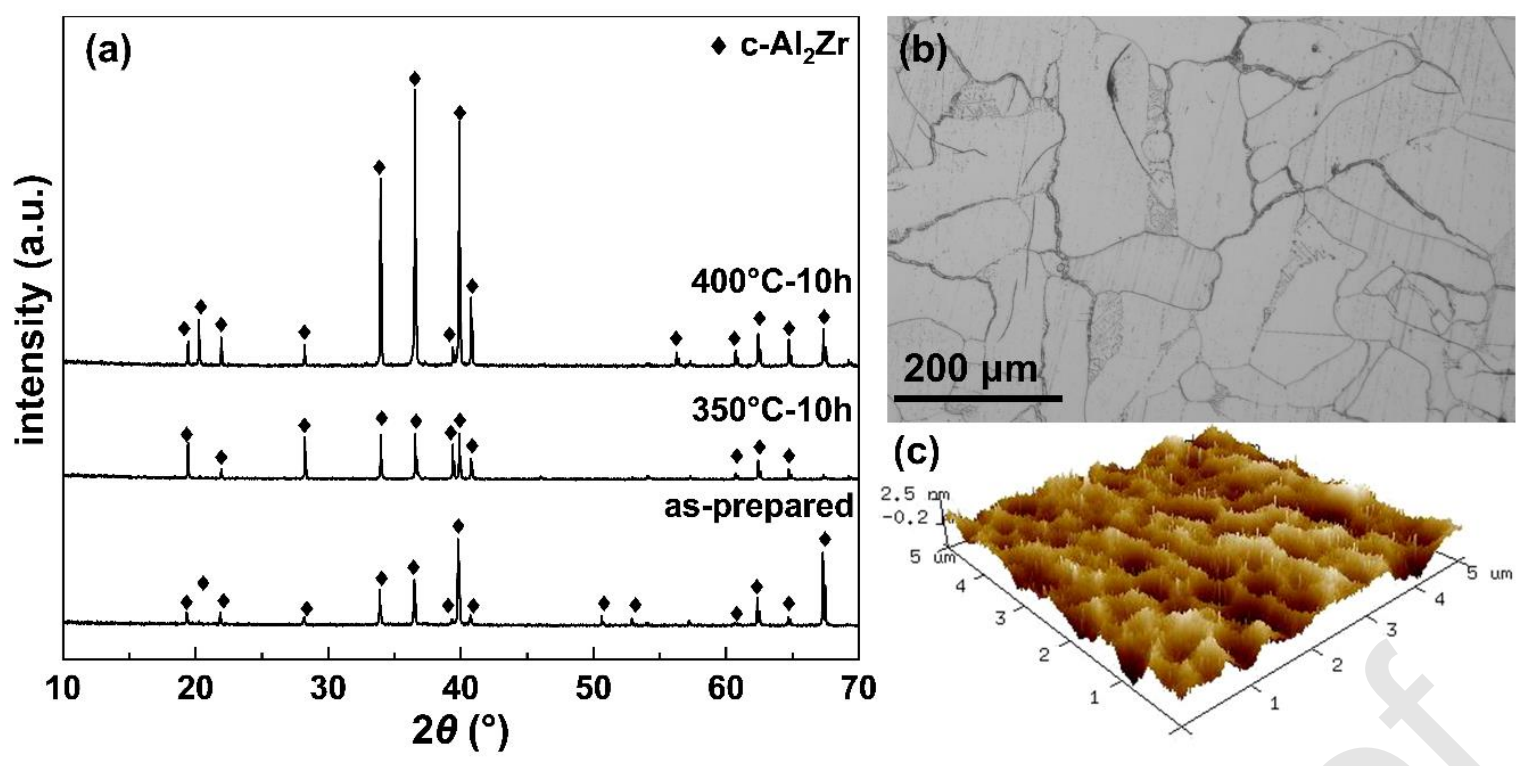

Fig. 1 (a) X-ray diffraction (XRD) patterns and images obtained by (b) optical microscopy $(\mathrm{OM})$ and (c) atomic force microscopy (AFM) for the c- $\mathrm{Al}_{2} \mathrm{Zr}$ alloy. 

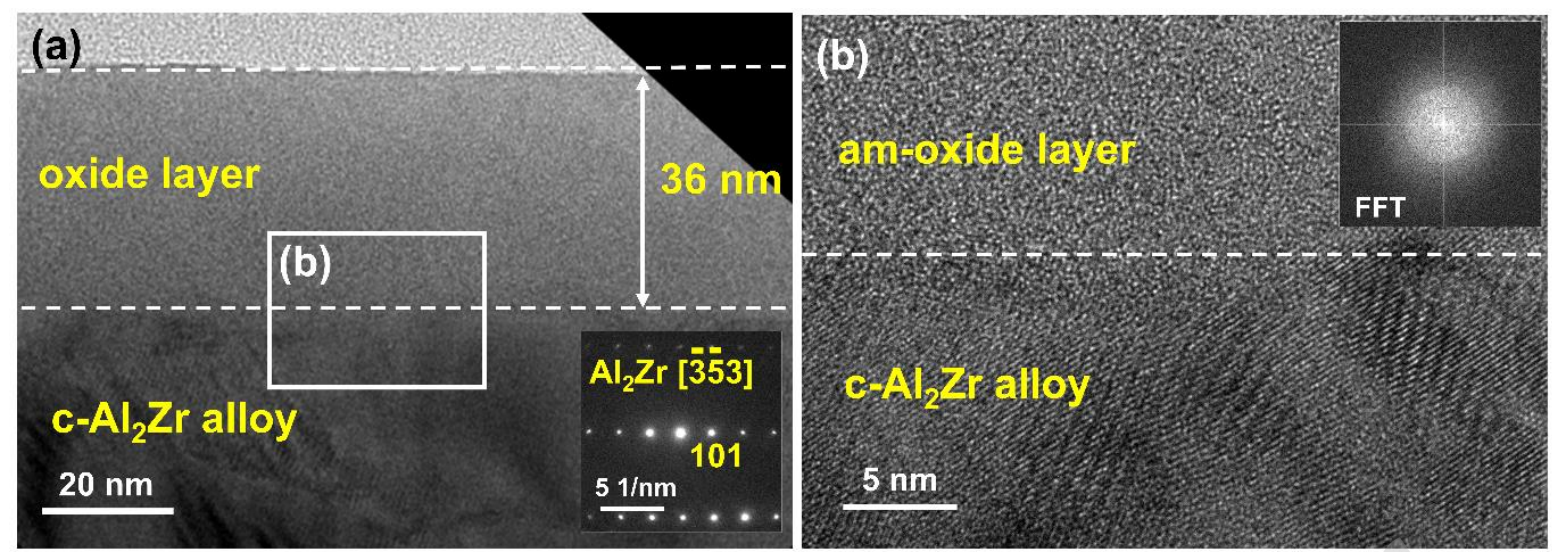

Fig. 2 (a) Cross-sectional transmission electron microscopy (TEM) image obtained for c- $\mathrm{Al}_{2} \mathrm{Zr}$ alloy oxidized at $400{ }^{\circ} \mathrm{C}$ for $10 \mathrm{~h}$, with the selected-area diffraction pattern of $\mathrm{c}-\mathrm{Al}_{2} \mathrm{Zr}$ alloy shown in the inset, and (b) high-resolution TEM image of the oxide/c- $\mathrm{Al}_{2} \mathrm{Zr}$ interfacial region marked by the rectangle in (a) and fast Fourier transform obtained exclusively within the oxide region. 

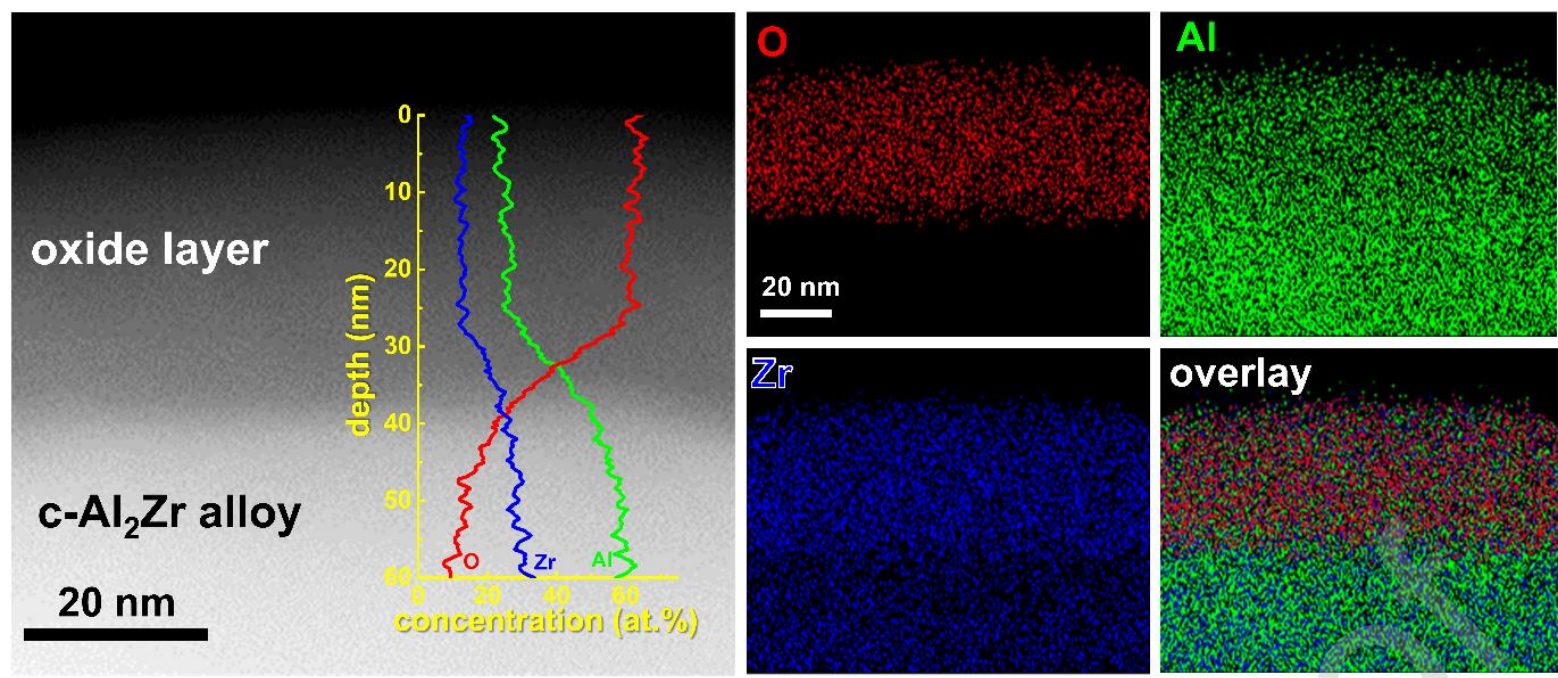

Fig. 3 Energy-dispersive X-ray spectroscopy (EDX) element line scan and mapping results for the c- $\mathrm{Al}_{2} \mathrm{Zr}$ alloy oxidized at $400{ }^{\circ} \mathrm{C}$ for $10 \mathrm{~h}$. 


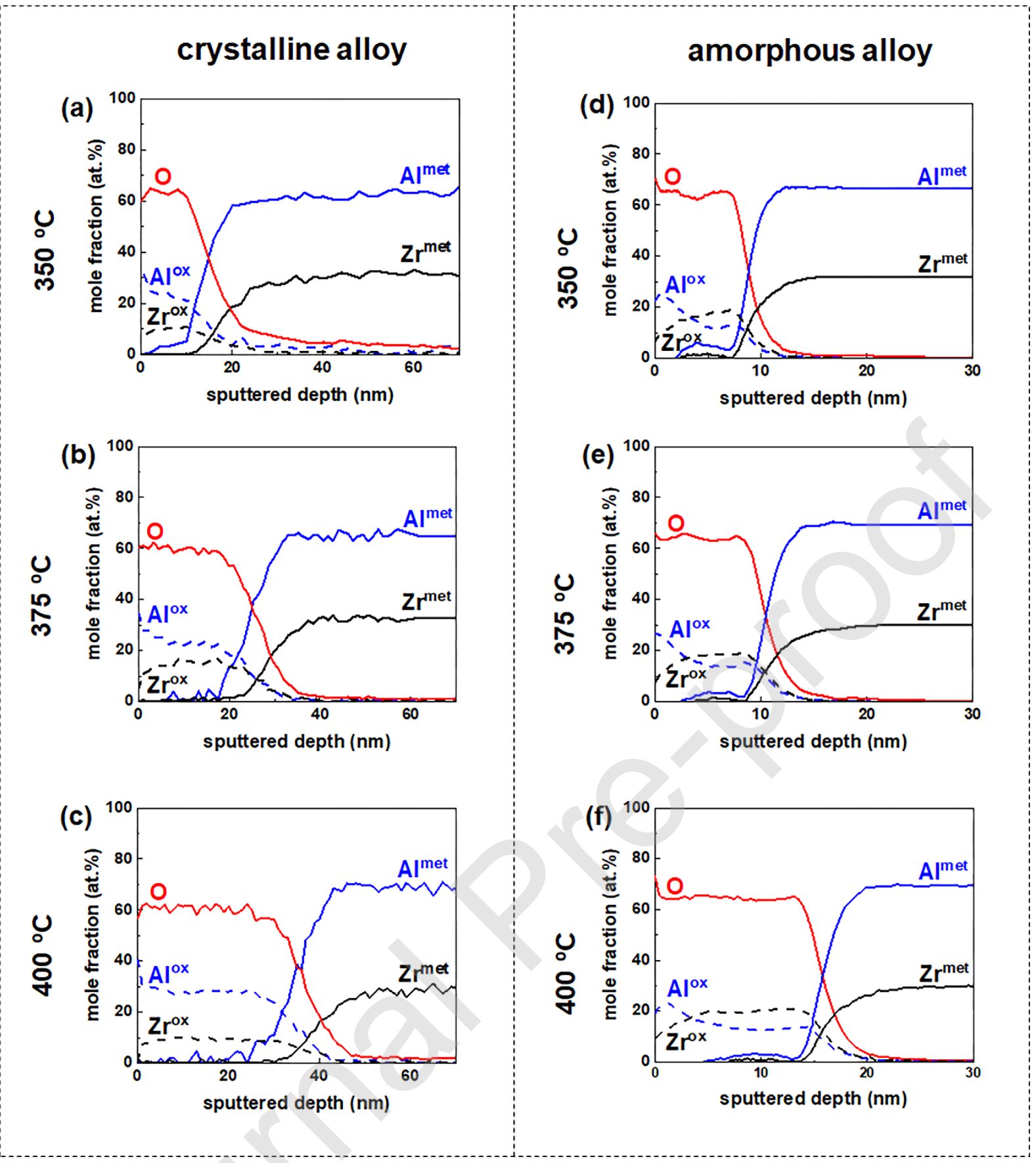

Fig. 4 Auger electron spectroscopy (AES) depth profiles for c- $\mathrm{Al}_{2} \mathrm{Zr}$ alloys oxidized at (a)

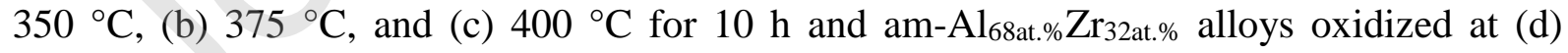
$350{ }^{\circ} \mathrm{C}$, (e) $375^{\circ} \mathrm{C}$, and (f) $400{ }^{\circ} \mathrm{C}$ for $10 \mathrm{~h}$. 

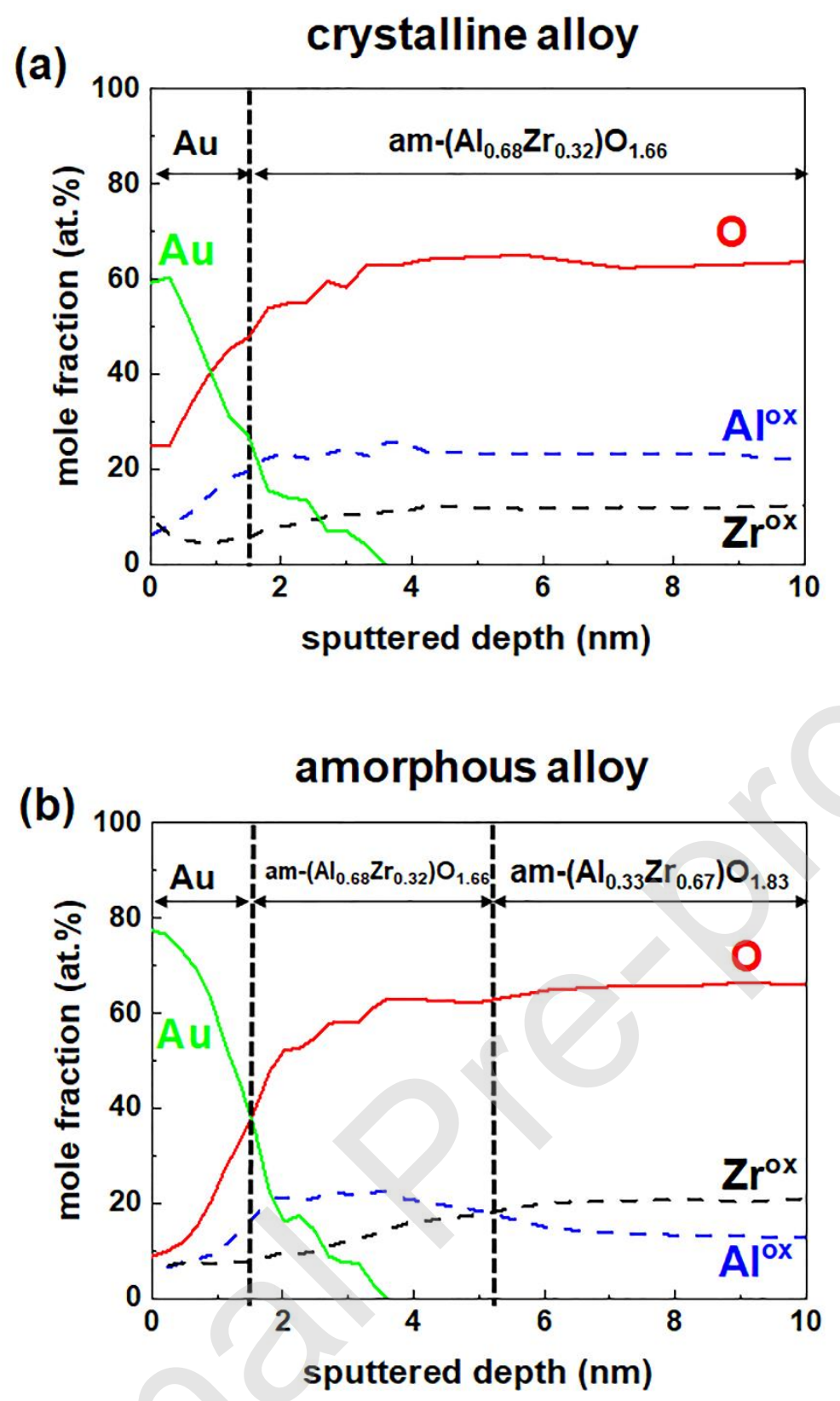

Fig. 5 Auger electron spectroscopy (AES) depth profiles for Au-labelled (a) c- $\mathrm{Al}_{2} \mathrm{Zr}$ and (b) am- $\mathrm{Al}_{68 a t . \%} \mathrm{Zr}_{32 \mathrm{at} . \%}$ alloys oxidized at $400{ }^{\circ} \mathrm{C}$ for $10 \mathrm{~h}$. 

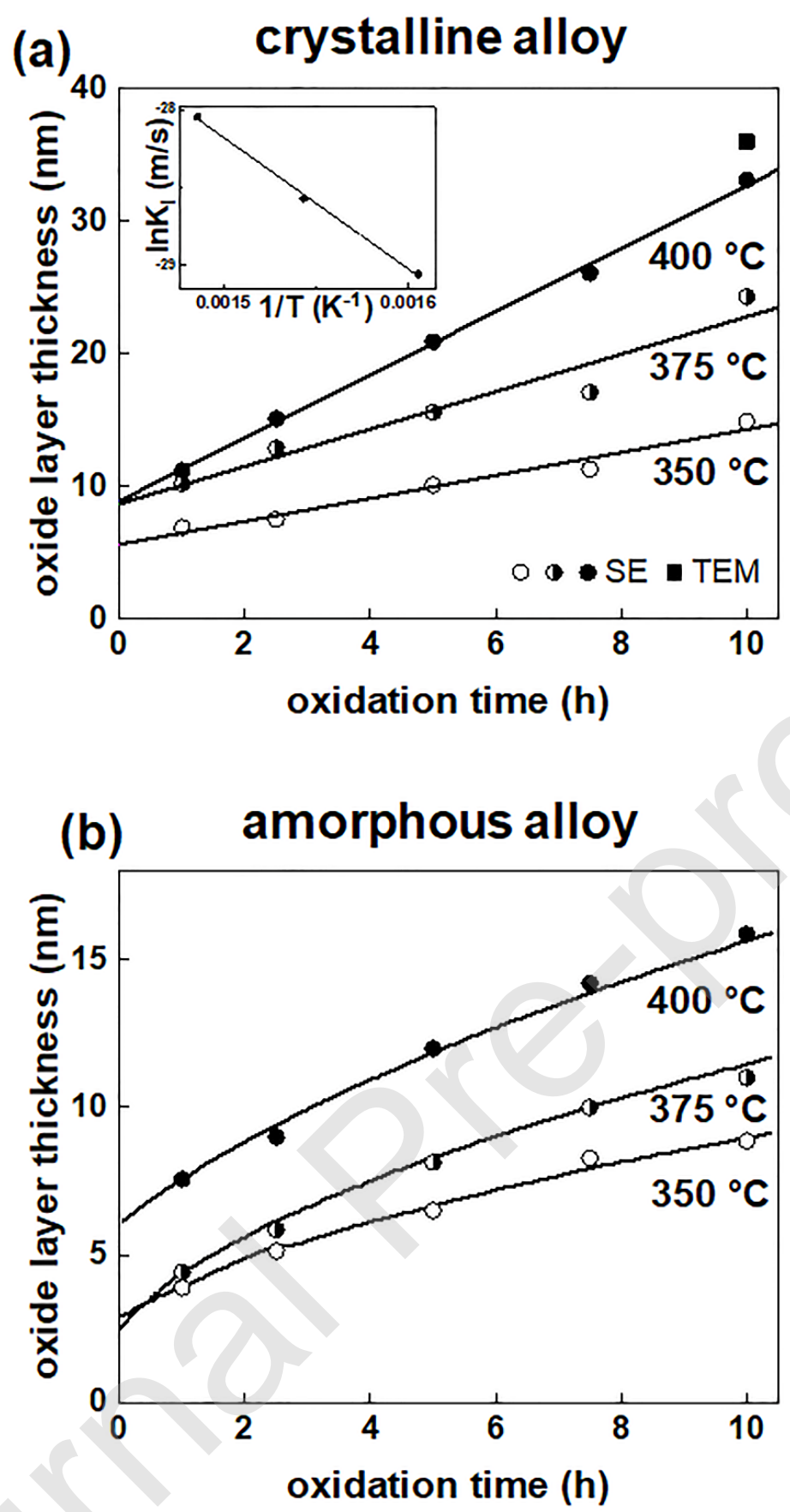

Fig. 6 Thicknesses of oxide layers on (a) c- $\mathrm{Al}_{2} \mathrm{Zr}$ alloy ( $\ln K_{1}$ for oxidation of c- $\mathrm{Al}_{2} \mathrm{Zr}$ alloy as a function of $1 / \mathrm{T}$ shown in the inset) and (b) am- $\mathrm{Al}_{68 \mathrm{at} . \%} \mathrm{Zr}_{32 \mathrm{at} . \%}$ alloy as a function of oxidation time at the temperatures of $350-400{ }^{\circ} \mathrm{C}$. 

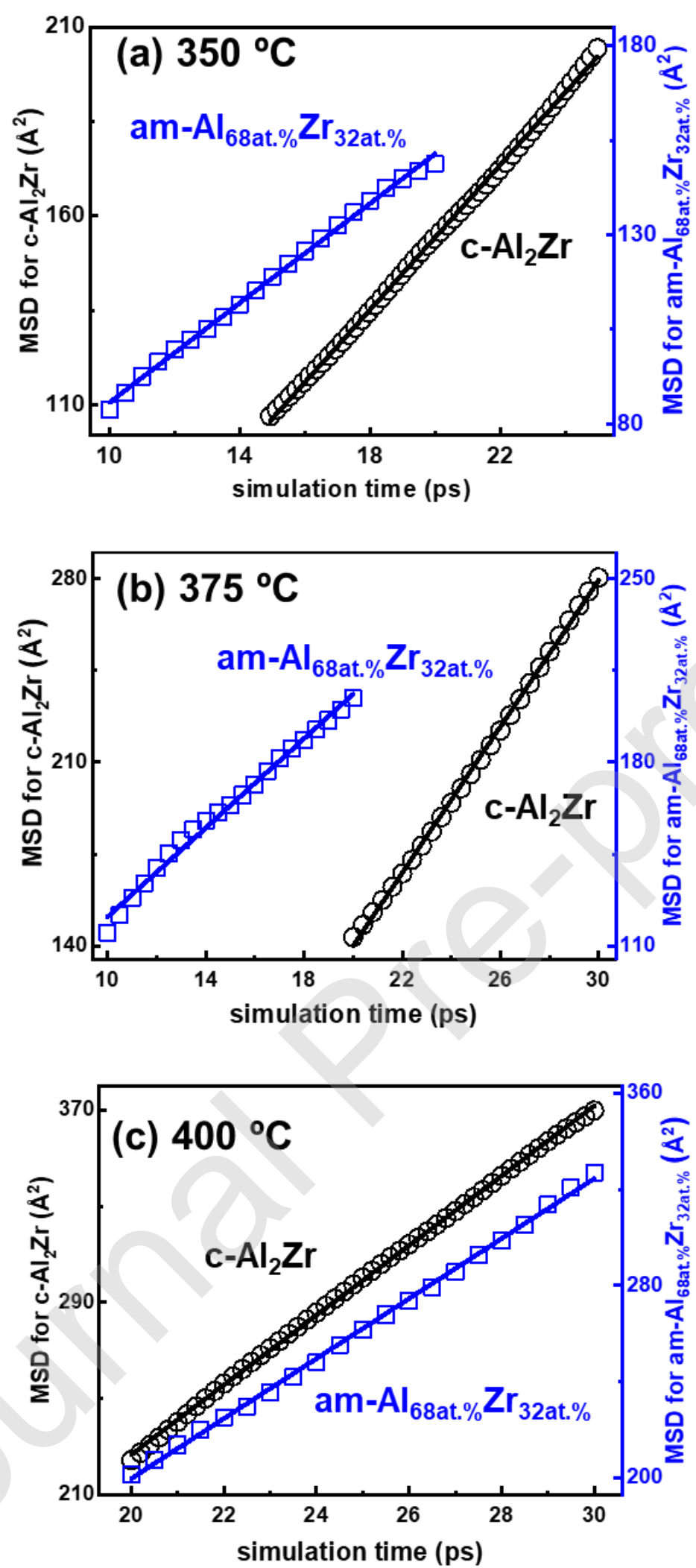

Fig. 7 Mean square displacements (MSD) for c- $\mathrm{Al}_{2} \mathrm{Zr}$ and am- $\mathrm{Al}_{68 a t . \%} \mathrm{Zr}_{32 \text { at. } \%}$ alloys at (a) $350{ }^{\circ} \mathrm{C}$, (b) $375^{\circ} \mathrm{C}$, and (c) $400{ }^{\circ} \mathrm{C}$. 